\title{
Adherence to treatment in patients with cystic fibrosis
}

\author{
Adesão ao tratamento em pacientes com fibrose cística
}

\section{To the Editor:}

After reading for the second time the article authored by Dalcin et al. and published in the Brazilian Journal of Pulmonology in 2007,(1) 1 would like to relate my own experience at the same facility.

1 graduated in 1997. Four years later, 1 was invited to treat patients with cystic fibrosis at the Hospital de Clínicas de Porto Alegre (HCPA, Porto Alegre Hospital de Clínicas), in Porto Alegre, Brazil. At the time, 1 had little knowledge of the disease, and it was a challenge to treat these patients, who, having been so diagnosed, were condemned to an early death.

In the first days of working at the HCPA, when entering ten south (the south wing of the tenth floor), 1 was greeted with a true harmony of sounds arising from the use of a thoracic maneuver known as "tapotement" (percussive tapping), typically performed by the mother of the patient, which elicited cough with expectoration. These sounds emanated from the rooms in which one would find the patients hospitalized with this terrible genetic disease, the evolution of which, until recently, did not allow its victims to live to be adolescents. Due to better treatment regimens, the survival of these patients has been increasing, and it currently possible for cystic fibrosis patients to reach up to 35 years of age. ${ }^{(1)}$

The treatment is based on respiratory therapy two to three times a day, regular physical activities and antibiotic therapy, together with nutritional and psychological support, and nursing care.

It is important to remember that one of the objectives of respiratory therapy is to maintain the airways unobstructed, allowing adequate gas exchange.

At that time, we performed the conventional chest physical therapy, which included vibration, postural drainage and cough.

Step by step, based on the international literature, we built a new model of treatment that met the individual needs of each patient. We instituted the use of continuous positive airway pressure masks, autogenic drainage, active cycle of breathing techniques and other procedures, all with strong foundations in physiology.

These advances promoted greater patient autonomy. We expected this new proposal to increase patient adherence to treatment. However, according to various studies, adherence to respiratory therapy falls short of what is expected. This has been the target of many studies. In one such study, treatment adherence was reported to be between $40 \%$ and $53 \%{ }^{(2)}$ In another study, 91 patients between 14 and 40 years of age completed a questionnaire, in which $41 \%$ of the patients reported having complied well with respiratory therapy. ${ }^{(3)}$ In the study conducted by Dalcin et al., the self-reported degree of adherence to respiratory therapy was $84 \%$; however, these are subjective measurements which often overestimate adherence. ${ }^{(1)}$

According to Kaplan, there is no clear association between adherence and gender, nor does adherence correlate with marital status, race, religion, socioeconomic status, intelligence or education level, and this finding is not specific for patients with cystic fibrosis. ${ }^{(4)}$

It is of note that adherence has been shown to be greater among younger patients, who therefore present less disease severity. ${ }^{(5)}$

This is most likely due to the constant involvement of the mother of the patient; in one study, it was demonstrated that, for whatever reason, the treatment does not seem to be effective without the aid of the mother. ${ }^{(6)}$

In conclusion, 1 hope that, in the near future, we all make efforts to identify the causes of poor adherence, and that we have more efficacious strategies of treatment, since there is no point in promoting independence in self-care if there is no awareness of how important and fundamental it is for the maintenance of the quality of life and, above all, for increasing the survival of these patients.

\section{Jefferson Veronezi}

Professor at the Porto Alegre

Methodist University Center Institute, Porto Alegre, Brazil

$$
\begin{gathered}
\text { Daiane Scortegagna } \\
\text { Physical Therapist }
\end{gathered}
$$

Associação de Apoio a Portadores de Mucoviscidose do Rio Grande do Sul - AMUCORS, Rio Grande do

Sul Mucoviscidosis Patient Support Association - Novo Hamburgo, Brazil 


\section{References}

1. Dalcin PT, Rampon G, Pasin LR, Ramon GM, Abrahão $\mathrm{CL}$, Oliveira VZ. Adherence to treatment in patients with cystic fibrosis. J Bras Pneumol. 2007;33(6):663-70.

2. Abbott J, Dodd M, Gee L, Webb K. Ways of coping with cystic fibrosis: implications for treatment adherence. Disabil Rehabil. 2001;23(8):315-24.

3. Conway SP, Pond MN, Hamnett T, Watson A. Compliance with treatment in adult patients with cystic fibrosis. Thorax. 1996;51(1):29-33.
4. Sadock BJ, Sadock VA, Dornelles CO, editors. Compêndio de Psiquiatria - Ciência do Comportamento e Psiquiatria Clínica. Porto Alegre: Artmed; 2007. p. 1-14.

5. Arias Llorente RP, Bousoño García C, Díaz Martín JJ. Treatment compliance in children and adults with cystic fibrosis. J Cyst Fibros. 2008;7(5):359-67.

6. Oliveira VZ, Gomes WB. Comunicação médico - paciente e adesão ao tratamento em adolescentes portadores de doenças orgânicas crônicas. Estud psicol (Natal). 2004;9(3):459-69. 